\title{
Problems and Practice of Menstrual Hygiene among Adolescent Girls
}

\author{
Deep Bahadur Adhikari \\ Central Department of Education, Tribhuvan University \\ Kirtipur, Nepal \\ Email: dip.bdr@gmail.com \\ DOI: 10.31364/SCIRJ/v6.i6.2018.P0618562 \\ http://dx.doi.org/10.31364/SCIRJ/v6.i6.2018.P0618562
}

\begin{abstract}
The paper is based on the study of adolescent's girls and their menstrual practices of 3 secondary schools of Besishahar municipality Lamjung. Simple random sampling method was used for the respondent selection. Where 40 girls were taken from grade 9and 10 from each school. The study showed $92.97 \%$ girls having basic idea about menstruation whereas rest of $7.03 \%$ found to be unaware. The knowledge regards to menstruation among girls resulted satisfactory. The first menstruation was started in the age of 13 to 14 among two third of the girls as they responded; indicates their menstrual cycle is normal. About $50 \%$ girls shared their unwillingness for working during the period. Two thirds of the girls told about their practice of separate staying for 4 to 5 days in each menstruation and family does not allow them to get entry into the kitchen and so called sacred places of the house where as $20 \%$ girls showed their faith in god and sin and follow menstrual practices due to fear of being sinner. With the sanitary point of view, $26 \%$ girls expressed their habit of using sanitary pad while rest of $74 \%$ shared that they used piece of cloth as safety. Likewise, $80(66 \%)$ have found to be having daily bathing during the period. Most of the girls $(\mathbf{9 4 . 2 \%})$ shared about their physical pain with the problem like anemia and extreme bleeding and $90 \%$ found be affected from psychological problem. $20 \%$ talked about these sufferings. We found, $19.01 \%$ were forced to be absent in school in those days. Similarly, 64\% told about their regular menstruation.
\end{abstract}

Index Terms - Menstruation, Menarche, Menopause, Depression, Anxiety, Nausea, Anemia

\section{INTRODUCTION}

Menstruation is the regular discharge of blood or mucosal tissue from the inner lining of the uterus through the vagina for 4-5 days in every 28 days during reproductive life of women. A woman's first menstruation is termed as menarche and it occurs typically around age of 12-13 years and stops generally 45-50 years that is termed menopause. Menstruation process occurs regularly every month, so this is called menstruation cycle. To be menarche is a sign of maturity to reproduction and after menopause woman lose her reproductive power and cannot bear the child. Though it is natural process woman face many physiological and psychological changes during that time.

Accordance with Hewision (1996) in most of the girls, menarche occurs in 11-16 years. Irregular menstruation and abdominal pain are common in most unmarried women but it has no bad effect. In this condition, heavy work and exercise are adventitious. Hot drinks, massage of heating pad in lower abdomen, and keeping feet in hot water may relief. In menstruation, balanced diet, light work, personal and perennial hygiene and using clean pad are beneficial.

FAPAN (2000) study among 12-15 years girls of 5 districts of Nepal reported the mean age of menarche was 13.7 years and $65 \%$ of them reported they were kept in isolation at the time of menarche.

According to Hindu culture, menstruation is believed to be curse given by god to women and they are considered as untouchable. They are forced to stay separately with separate daily usage materials like mat blanket and straw beds. If child is touched by the menstruate girl, he/she should be bated every morning to make touchable for others (1. loyd, 1969).

Our society believes that if they touch tree, it will be ruined and the places people will be defiled. If they drink milk products, the cow and buffaloes will become sick. In western part of Nepal, we see the rituals of 'Chhaupadi' that means menstruate girls are sent to stay at a small hut distant from the village till the menstrual period is over. Unsafe habitant and unhygienic environment lead them to different physical and psychological problems.

Because of different beliefs, values and norms of the society, adolescent girls are compelled to adopt unhygienic health rules even if they know what right is. So, women in specially Nepal are vulnerable to suffer from reproductive health problems.

Adolescents female are in great risk in developing countries like Nepal because due to lack of knowledge on reproductive health and sexual health. They are suffering from different problems during menstruation like harassment, early marriage, early intercourse, early and complicated pregnancy, transmission of STD and other reproductive tract infection. So, it is necessary to assess and solve the reproductive health status and problems of the adolescent's girls.

The issue of menstrual hygiene is inadequately acknowledged and has not received proper attention. Use of sanitary pads and washing the genital area are essential practices to keep the menstrual hygiene. Unhygienic menstrual practices can affect the health of the girls and there is an increased vulnerability to reproductive tract infections and pelvic inflammatory diseases and other complications.

Hence, the aim of this paper is to identify the problems and practice regarding menstrual health of adolescent girls.

\section{MATERIALS AND METHODS}

This is a descriptive type of research based on quantitative data. Besishahar Municipality Lamjung was the area of this 
study. All the girls' students having studied in six secondary schools of class $9 \& 10$ of that area were the population of the study. For the sampling, among six secondary schools of Beshishahar municipality, Lamjung three schools were selected purposively and 20/20 girls from 9 and 10 classes from each school were selected with the simple random sampling lottery method. In total 120 girls were taken as the sample. Interview schedule was applied as main tools of this study. Books papers, reports were also used as secondary sources.

\section{RESULTS AND DISCUSSION}

According to the data obtained from the fields following result are found and discussed as below in different sub headings.

\section{a. Personal characteristics of the respondent girls}

The respondents of this study were age between 13-19 years. According to castes Brahmin Chhetri-60\%, Janajati 35 and 5\% were Dalit. According to religion $84 \%$ girls were Hindu and $16 \%$ were Buddhist. The study area is hilly part of Nepal.

\section{b. Knowledge about menstruation}

There was a question to the respondent about the meaning of menstruation most of $(92.97 \%)$ the girls responded menstruation as a normal physiological function in the women body; while $7.03 \%$ expressed they were unknown about it. Data revealed that level of knowledge about menstruation is satisfactory among the respondent girls. There was a question also about previous knowledge about menarche, $70 \%$ girls replied they had knowledge about menarche and 30\% had no knowledge about menstruation before menarche.

\section{c. Age of first menstruation (menarche) and its regularities}

Menstruation starts in girls in different age that depends upon heredity, diet and also their living patterns. Most of the girls started menstruation in 11-16 years (Hewision, 1996). Age of the first menstruation of the respondents of this study is given in Table I.

TABLE I. DISTRIBUTION OF RESPONDENTS BY AGE OF FIRST MENSTRUATION

\begin{tabular}{|c|c|c|c|}
\hline S.N. & $\begin{array}{c}\text { Age at first } \\
\text { menstruation (year) }\end{array}$ & Number & Percent \\
\hline 1 & 11 & 4 & 3.33 \\
2 & 12 & 17 & 14.16 \\
3 & 13 & 34 & 28.33 \\
4 & 14 & 42 & 35 \\
5 & 15 & 21 & 17.5 \\
6 & 16 & 2 & 1.66 \\
\hline & Total & $\mathbf{1 2 0}$ & $\mathbf{1 0 0}$ \\
\hline
\end{tabular}

Source-Field survey (2073)

Table I shows that about two third of the girls have started their first menstruation between 13 to 14 years; no one had started menstruation before eleven or after 16 years. It indicates that all respondents have normal age range of starting first menstruation. Regularities in first menstruation cycle is important to women's health, study result showed $64 \%$ of girls replied had regular menstruation and rest $36 \%$ had not regular menstruation.
Generally, in Nepal girls are kept separate or isolated in menstruation period in bleeding phase that is 4-5 days. Results shows that $37.5 \%$ girls stayed with family, $11.6 \%$ in neighbor's house and $43.33 \%$ used to send their relatives house and $7.5 \%$ remain in in separate room in their own house.

TABLE VII. PLACE TO KEEP GIRLS DURING MENARCHE

\begin{tabular}{|c|l|c|c|}
\hline S.N. & $\begin{array}{c}\text { Places to keep during } \\
\text { menarche/ menstruation }\end{array}$ & Numbers & Percent \\
\hline 1 & With family & $\mathbf{4 5}$ & $\mathbf{3 7 . 5 0}$ \\
2 & Neighbor's house & $\mathbf{1 4}$ & $\mathbf{1 1 . 6 6}$ \\
3 & Relative's houses & $\mathbf{5 2}$ & $\mathbf{4 3 . 3 3}$ \\
4 & Separate room & $\mathbf{9}$ & $\mathbf{7 . 5 0}$ \\
& & & \\
\hline & Total & $\mathbf{1 2 0}$ & $\mathbf{1 0 0}$ \\
\hline
\end{tabular}

Source- Field survey (2073)

In the Hindu culture many family and community behaved menstrual girl as an untouchable. Many families have believed that brother and father should not see and touch their sister and daughter during first to third menstruation. At that time girls are kept away from home or separate room in their home. Brhamin and Chhetri caste group used to send their menstruated girls for 15 days and they are not allowed to see sun light as well as to see and meet their relatives. Other caste groups especially Janajati group didn't do so. They could remain their own house but they do not touch other people and do not go to kitchen. In the scientific point of view untouchable during menstruation is not accepted but this time girls should care more their health. They need to take healthy diets, proper cleanliness and should do light exercise.

\section{e. Duration of keeping separate from family during menstruation}

First four days of menstruation is called menstrual phase, in that phase blood is discharged from vagina. In that period girls are isolated. There was a question do you stay separate or untouchable during each menstrual period? They replied $69 \%$ girls were treated menstruation as an untouchable and $31 \%$ were not treated as untouchable. Among most of the girls who took menstrual period as touchable were kept separate from family for 4 to 5 days.

TABLE III. DURATION OF KEEPING SEPARATE FROM FAMILY DURING MENSTRUATION

\begin{tabular}{|c|c|c|c|}
\hline S.N. & No of Days & Numbers & Percent \\
\hline 1 & 3 & 14 & 11.6 \\
2 & 4 & 48 & 40 \\
3 & 5 & 51 & 42.5 \\
4 & 6 & 5 & 4.16 \\
5 & 7 & 2 & 1.66 \\
\hline & Total & $\mathbf{1 2 0}$ & $\mathbf{1 0 0}$ \\
\hline
\end{tabular}

Source- Field survey (2073)

\section{f. Reasons for isolation separate while menstruation}

In the point of view of health, isolation may prove reasonable because isolation in the sense take rest. There was a question about cause of isolation, $63 \%$ replied due to a family pressure, $20 \%$ due to for easy feeling and $16.66 \%$ took perception of not being isolation as sinful work.

TABLE IV. REASONS FOR KEEPING SEPARATE WHILE MENSTRUATION

\section{d. Place to keep girls during menarche}




\begin{tabular}{|c|l|c|c|}
\hline S.N. & \multicolumn{1}{|c|}{ Yes/ reasons } & Numbers & Percent \\
\hline 1 & Family/ society's & 76 & 63.33 \\
2 & pressure & 24 & 20.00 \\
3 & On easy feeling & 20 & 16.66 \\
& It is sinful work & & \\
\hline & Total & $\mathbf{1 2 0}$ & $\mathbf{1 0 0}$ \\
\hline
\end{tabular}

Source- Field survey (2073)

g. Care given to girls during menstruation by the family

Care given by the family to the girls during menstruation plays important role in their health. In this study one third of the girls didn't find any care or they did as usual care practice during menstruation. And $26.6 \%$ found hygienic and nutritional food during menstruation period, 16.66 found sympathy for mental and emotional problems, $26.66 \%$ found rests and $6.66 \%$ found appropriate health care.

TABLE V. CARE GIVEN TO THE GIRLS DURING MENSTRUAL PERIOD IN THE FAMILY

\begin{tabular}{|c|l|c|c|}
\hline S.N. & $\begin{array}{l}\text { Types of care given by the } \\
\text { family }\end{array}$ & Number & Percent \\
\hline 1 & Hygienic and nutritional food & 32 & 26.60 \\
2 & Sympathy for mental and & 20 & 16.66 \\
3 & emotional problems & 20 & 16.66 \\
4 & Rest & 8 & 6.66 \\
5 & Appropriate health facilities & 40 & 33.39 \\
& Nothing special & & \\
\hline
\end{tabular}

Source- Field survey (2073)

Similarly, concerning their sanitation, $26 \%$ used sanitary pad and 74\% used other type of clothes. Likewise, 80(66\%) found daily bathing in menstrual period.

\section{h. Physical problems faced by the girls during menstruation}

Girls may have many physical problems during menstruation due to its natural as well as other causes. Keeping this fact in the mind researcher asked to the respondent about what were the problems faced by them during menstruation. Answering that question $94.21 \%$ respondent replied they had any kinds of physical problem during menstrual period and $5.78 \%$ had no any physical problems. The physical problems they faced were lower abdominal pain $60 \%$, excess bleeding $20 \%$, nausea $27 \%$, headache $9 \%$ and $4 \%$ were anemia. Among those symptoms lower abdominal pain, nausea, and headache are generally seen in menstrual girls but anemia and excess bleeding which are seen on about $20 \%$ girls show the poor sign of health.

TABLE VI. TYPES OF PHYSICAL PROBLEMS FACED BY THE GIRLS DURING MENSTRUATION

\begin{tabular}{|c|l|c|c|}
\hline S.N. & $\begin{array}{c}\text { Types of problems } \\
\text { faced during } \\
\text { menstruation }\end{array}$ & Number & Percent \\
\hline 1 & Lower abdominal pain & 60 & 50 \\
2 & Excess bleeding & 20 & 16.6 \\
3 & Nausea & 27 & 22.5 \\
4 & Headache & 4 & 7.5 \\
5 & Anemia & 120 & 3.33 \\
\hline & Total & & 100 \\
\hline
\end{tabular}

Source- Field survey 2073

i. Psychological problems faced by the girls during menstruation
Besides physical problems girls may have also faced psychological problems during menstruation. Hence researcher asked the questions to the respondent girls about psychological problems they had faced. Answering the question $50 \%$ expressed they had felt no interest on work, $26.6 \%$ replied they had no interest in talk. $10 \%$ felt depression and $5 \%$ facing with anxiety and only $8.33 \%$ expressed they had no any problem.

TABLE VII. TYPES OF PSYCHOLOGICAL PROBLEMS FACED DURING MENSTRUATION

\begin{tabular}{|c|c|c|c|}
\hline S.N. & $\begin{array}{c}\text { Types of problems faced } \\
\text { during menstruation }\end{array}$ & Numbers & Percent \\
\hline 1 & No interest to work & 60 & 50 \\
2 & No interest to talk & 32 & 26.6 \\
3 & Depression & 12 & 10 \\
4 & Anxiety & 6 & 5 \\
5 & No any problem & 10 & 8.33 \\
\hline & Total & $\mathbf{1 2 0}$ & $\mathbf{1 0 0}$ \\
\hline
\end{tabular}

Source- Field survey (2073)

Above data indicate that most of the girls faced any kind of psychological problem during menstruation. Depression and anxiety which are seen in $15 \%$ girls that indicates poor sign of their health. The reasons may be menstruation is a sensitive period; their tissues and organs become weak in this time, and psychologically also they feel uneasy. The cultural factors also may affect to their adjustment. Due to menstruation 23(19.01) respondents expressed they had also missed their school.

\section{CONCLUSIONS}

While observing the data in surface, the knowledge about menstruation among respondent groups seems satisfactory. But only basic idea is not adequate, serious concern about this is highly needed. Menstruation is a regular process and occurrence of problems during the period is common to all physical pain, weakness, extreme bleeding, anxiety, family ignorance, unhygienic atmosphere, separate living, lack of hygienic pads are some of the problems that female are usually facing regularly. They are also being psychologically victimized because it's a critical phase; they need family love, support, friendly behavior and special care. Females themselves should be aware about their physicality, its changes, menstruation cycle, personal hygiene, balance die, possible harm and reproductive disease, maternal health, their rights regarding health etc. the female health education should be given to them since earlier days. Senior members of family, teachers and friends can be taken as best guidance for this purpose. The evil practices of society and misconception about menstruation must be avoided. For this, special awareness program in society is essential. Truly, it's difficult to change the practices of the society and the concept of older generation; it takes time, but not impossible.

\section{REFERENCES}

[1] Best J. W \& Khan J.V. (1999). Research in Education (7th Ed) New Delhi; Prentice Hall of India.

[2] FPAN (2000). A study on reproductive health of women in five districts, author:

[3] Hwision, A. (1996). Dysmenorrheal menstrual attitude and G. p consultation. British Nurses Journal. 
[4] Jalane Mekonnenn Tesfalidet Tekelab \& Shialeela P. Upash (2015) Assessment of knowledge and practice of menstrual hygiene among high school girls in Western Ethiopia BMC Women's health 2015; 84 DOI;10 1186/s 12905-015-0245-7

[5] Louis Cohen, lawerence Manion \& Keith morrision (2016) Research methods in Education (6th ed.) Routeldge Tylor \& Francis Group London and New York.

[6] MPDS (2003) Chupadi, Dadeldhura, multipurpose Development Society
[7] Oche M, Umar A, Gana G, Ango J: Menstrual health: the unmet needs of adolescent girls in sokooto, Nigeria. sci Res Essays. 2012, 7 (30): 410-418.

[8] Prateek S, Saurabh R: A cross sectional study of knowledge and practices about reproductive health among female adolescents in an urban slum of Mumbai. J Fam Reproductive health. 2011, 5(4): 117-124. 